Brain, Behavior and Evolution

\title{
Timothy J. Neary (1948-2009) A Gifted Comparative Neuroanatomist
}

Timothy J. Neary, age 60, irrepressible free spirit and insightful scholar, died April 6, 2009, at his daughter's home in Omaha, Nebraska, after a long battle with multiple sclerosis. Tim's academic career was unfortunately cut short several years before his death by the erosive effects of his debilitating disease, but his excellent publications and professional activities had already made a substantial and enduring contribution to his field.

Tim was born August 30, 1948 in Pasadena, CA but spent his formative years in the Chicago area and was proud to have graduated from prestigious New Trier High School in Winnetka, Illinois, in 1965 . He did his undergraduate work in biology at Case Institute of Technology in Cleveland, Ohio and remained there to receive his $\mathrm{PhD}$ in Anatomy, under Theodore J. Voneida, from Case Western Reserve University in 1975. During his graduate work, Tim became closely associated with my laboratory, and he later followed me to the University of Michigan in Ann Arbor for postdoctoral work. For the next several years, he collaborated with me and other laboratory members on a series of papers that are still frequently cited. His analysis of the cytological organization of the diencephalon in anuran amphibians, for example, has stood the test of time with only minor modifications, and he also made major contributions to our understanding of the connections of the dorsal thalamus in these animals.

In 1977, Tim became Assistant Professor of Anatomy at Creighton University in Omaha, Nebraska, where he remained throughout his academic career. While at Creighton, Tim blossomed from a somewhat reticent speaker into a fine lecturer and a much loved teacher, honored with awards and esteemed by students. He di-

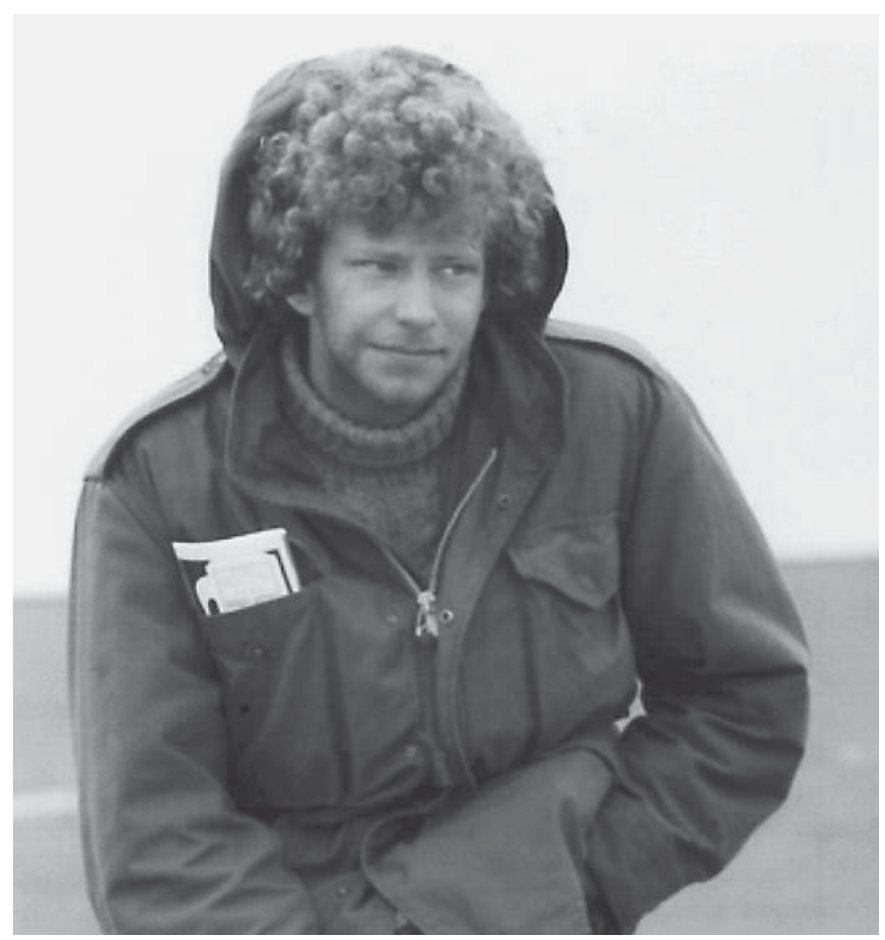

In all things of nature there is something of the marvelous. Aristotle (384 BC-322 BC), Parts of Animals

rected the Neuroscience Program at Creighton and made the Neuroscience class a favorite with the university's medical students. In addition, he mentored several high school students, sharing his love of science with them as he helped with their projects. Tim was also instrumental in forming a nucleus of talented young researchers in evolutionary and developmental neurobiology at Creigh-

\section{KARGER}

Fax +41613061234 E-Mail karger@karger.ch www.karger.com
R. Glenn Northcutt, PhD

Department of Neurosciences, 0201

University of California, San Diego

La Jolla, CA 92093 (USA)

Tel. +1 8585345612 or 673-7364, Fax +1 858534 5622, E-Mail rgnorthcutt@ucsd.edu 
ton, and with these colleagues, he again published several significant contributions. In particular, his experimental studies of the limbic system in reptiles (in collaboration with Laura Bruce) laid the foundation for our current understanding of amygdalar organization in tetrapods, including the realization that the dorsal ventricular ridge of reptiles is homologous to the pallial amygdala in mammals, not to mammalian isocortex.

Tim could be, by turns, exasperating and exhilarating. He was incapable of conversation when the subject did not interest him, but fortunately for those who knew him, his interests were legion. He was a consummate naturalist, who loved the out-of-doors and camping in the mountains, and he was a tireless reader, who would enthusiastically recommend his latest book-finds in widely divergent areas. He was a political and social activist with a liberal bent. After moving to Cleveland in the fall of 1968 , Mary Sue and I first met Tim, not in the halls of academe, but in the parking lot of a local grocery store, where he charmingly persuaded us to shop elsewhere, due to a boycott of non-union lettuce. He was also inexhaustible. Other lab members and friends joked about having 'Timothy duty'. That meant that someone stayed up 'til dawn and talked to Tim when there were late-night parties in our room at national meetings, so that Mary Sue and I could go to bed.

Tim was a founding member of the J.B. Johnston Club and an enthusiastic supporter of the Club for all his professional life. He served on the Program Committee, coorganized the 9th Annual Karger Workshop at JBJC, and was an enthusiastic discussant at all Workshops and Club meetings.

As his publications indicate, Tim was a lover of amphibians, particularly ranid frogs. During one national meeting, I still remember him gleefully traveling across Los Angeles with a huge, brightly painted, Mexican pottery bullfrog, which he'd just purchased and which thereafter occupied a place of honor on a lab bench in Ann Arbor.

Half Polish and half Irish - it was said that his smile was that of a Polish leprechaun - Tim delighted in the number of Polish researchers who were in, or friends of, my laboratory, and the rest of us were treated to the annual meeting of the Polish Neuroanatomical Society, held spontaneously during room-parties at national meetings. He was especially pleased when his mirror image joined my lab, a young Irish-Polish student whom Tim took pains to make comfortable at his first meeting, just as he had earlier adopted an Italian-Polish fellow frog-lover who became a student with me. Another (Irish) student recalls Tim providing a first ride in a BMW and a conversation about science and scientists. It occurs to me now that such gestures on Tim's part were probably instrumental in establishing the sense of continuity in my laboratory that has always been a source of great satisfaction to me and to Mary Sue also.

Insatiably inquisitive, Tim was a social chameleon who liked the best of everything but took what was available and was never pretentious. At a time when it is no longer fashionable to call oneself a comparative neuroanatomist, Tim would have been happy to claim being exactly that, and he would have continued to enhance the field with his talent and his sense of excellence.

Tim is survived by his daughter, Katherine Neary, of Omaha, Nebraska, and his mother, Stefany Neary, of Glenview, Illinois.

\author{
R. Glenn Northcutt \\ Mary Sue Northcutt, La Jolla, Calif.
}

\section{List of Publications}

Research Papers

Neary TJ, Wilczynski W (1977) Ascending thalamic projections from the obex region in ranid frogs. Brain Res 138:529-533.

Northcutt RG, Neary TJ, Senn DG (1978) Observations on the brain of the coelacanth, Latimeria chalumnae. J Morphol 155:181-192.

Neary TJ (1980) [Review of] Sensory Systems of Primates (Noback CR, ed). Folia Primatol 33: 159-160.

Neary TJ, Northcutt RG (1983) Nuclear organization of the bullfrog diencephalon. J Comp Neurol 213:262-278.
Neary TJ (1984) Anterior thalamic nucleus projections to the dorsal pallium in ranid frogs. Neurosci Lett 51:213-218.

Neary TJ, Wilczynski W (1986) Auditory pathways to the hypothalamus in ranid frogs. Neurosci Lett 71:142-146.

Neary TJ (1988) Forebrain auditory pathways in ranid frogs. In: The Evolution of the Amphibian Auditory System (Fritzsch B, Ryan MJ, Wilczynski W, Hetherington TE, Walkowiak W, eds), pp 233-252. New York: Wiley.
Neary TJ (1990) The pallium of anuran amphibians. In: Comparative Structure and Evolution of Cerebral Cortex. Cerebral Cortex, vol 8A, Part 1 (Jones EG, Peters A, eds), pp 107138. New York: Plenum Press.

Bruce LL, Neary TJ (1995) Afferent projections to the ventromedial hypothalamic nucleus in a lizard, Gekko gecko. Brain Behav Evol 46: 14-29.

Bruce LL, Neary TJ (1995) Afferent projections to the lateral and dorsomedial hypothalamus in a lizard, Gekko gecko. Brain Behav Evol 46:30-42. 
Bruce LL, Neary TJ (1995) The limbic system of tetrapods: a comparative analysis of cortical and amygdalar populations. Brain Behav Evol 46:224-234.

Fritzsch B, Neary TJ (1995) The octavolateralis system of mechanosensory and electrosensory organs. In: Amphibian Biology, Vol 3: Sensory Perception (Heatwole H, Dawley EM, eds), pp 879-922. Chipping Norton, NSW, Australia: Surrey Beatty \& Sons.

Neary TJ (1995) Afferent projections to the hypothalamus in ranid frogs. Brain Behav Evol 46:1-13

Neary TJ, Fritzsch B (1998) Development and Evolution. Proceedings of the 9th Annual Karger Workshop at the J.B. Johnston Club. Brain Behav Evol 52:175-253.

Abstracts

Neary TJ (1974) Diencephalic efferents of the torus semicircularis in the bullfrog, Rana catesbeiana. Anat Rec 178:425.

Neary TJ, Northcutt RG (1974) A re-evaluation of the anuran dorsal thalamus. Am Zool 14: 1255.

Neary TJ (1975) Architectonics of the thalamus of the bullfrog (Rana catesbeiana): A histochemical analysis. Anat Rec 181:435-435.

Northcutt RG, Neary TJ (1975) Observations on the optic tectum of the coelacanth, Latimeria chalumnae. Am Zool 15:806.

Neary TJ (1976) An autoradiographic study of the retinal projections in some members of 'archaic' and 'advanced' anuran families. Anat Rec 184:487.
Neary TJ, Wilczynski W (1977) Autoradiographic demonstration of hypothalamic efferents in the bullfrog, Rana catesbeiana. Anat Rec 187:665.

Wilczynski W, Neary TH, Andry ML (1977) Somatosensory projections to the thalamus in ranid frogs. Soc Neurosci Abstr 3:95.

Neary TH, Northcutt RG (1979) Organization of the diencephalon in the bullfrog Rana catesbeiana. Anat Rec 193:635.

Neary TJ, Wilczynski W (1979) Anterior and posterior thalamic afferents in the bullfrog, Rana catesbeiana. Soc Neurosci Abstr 5: 144.

Neary TJ (1980) Hypothalamic efferents in ranid frogs. Anat Rec 196:135

Neary TJ, Wilczynski W (1980) Descending inputs to the optic tectum in ranid frogs. Soc Neurosci Abstr 6:629.

Neary TJ (1982) Forebrain projections to the obex region in ranid frogs. Soc Neurosci Abstr 8:765.

Neary TJ (1983) A caudal striatal division in ranid frogs. Soc Neurosci Abstr 9:1064.

Neary TJ, White JS (1983) AChE-positive areas in the forebrain in ranid frogs. Anat Rec 205: 141.

Wilczynski W, Neary TJ (1983) Descending projections from the torus semicircularis in ranid frogs. Anat Rec 205:215.

Neary TJ (1984) A lectin-peroxidase study of hypothalamic afferents in ranid frogs. Anat Rec 208:125.

Neary TJ (1985) Evidence for a quinto-frontal tract in ranid frogs. Anat Rec 211:137.
Neary TJ, Wilczynski W (1986) Auditory pathways to the hypothalamus in ranid frogs. Neurosci Lett 71:142-146.

Wilczynski W, Neary TJ (1986) Terminal field organization in the bullfrog torus semicircularis. Soc Neurosci Abstr 12:105

Neary TJ (1987) Ascending projections of the torus semicircularis in ranid frogs. Soc Neurosci Abstr 13:305.

Neary TH (1988) Connections of the main and accessory olfactory bulbs in ranid frogs. Soc Neurosci Abstr 14:55.

Neary TJ, Northcutt RG (1990) Septal area connections in ranid frogs. Soc Neurosci Abstr 16:129.

Neary TJ, Bruce LL (1991) Hypothalamic afferents in the tokay gekko. Soc Neurosci Abstr 17:651.

Bruce LL, Neary TJ (1992) Comparisons of forebrain groups in tetrapods. Soc Neurosci Abstr 19:997.

Neary TJ, Fritzsch B (1992) Stage and concentration specific effects of retinoic acid on the differentiation of Xenopus hindbrain and ear. Soc Neurosci Abstr 18:955.

Neary TJ, Bruce LL (1993) comparisons of forebrain groups in tetrapods. Soc Neurosci Abstr 19:997.

Boyer KL, Quinn TH, Neary TJ, Bakay RAE (1994) Quantitative ultrastructural analysis of motor neuron synaptic contacts in the mutant mouse spastic. Soc Neurosci Abstr 20: 831

Neary TJ, Wilczynski W (1994) Midbrain roofthalamic connections in ranid frogs. Soc Neurosci Abstr 20:1418. 